\title{
Interview with Dr Carmen M. Mangion on Catholic Nuns and Sisters in a Secular Age: Britain, 1945-19901
}

\author{
Heidi MacDonald \\ University of New Brunswick
}

Dr Carmen M. Mangion, author of the recently published Catholic Nuns and Sisters in a Secular Age: Britain, 1945-1990 (Manchester University Press, 2020), is a senior lecturer in Modern History in the Department of History, Classics and Archaeology at Birkbeck, University of London. Mangion was raised in Detroit by first-generation Maltese parents and moved to the UK for graduate studies, first on the history of Anglican women religious in Britain for her MA, and then to Roman Catholic women religious in England for her $\mathrm{PhD}$.

Catholic Nuns and Sisters in a Secular Age is Mangion's fourth book. She is perhaps best known for her widely respected 2008 monograph, Contested Identities: Catholic Women Religious in Nineteenth-Century England and Wales (New York: Manchester University Press, 2008), derived from her PhD. While Mangion's previous research is based on meticulous archival research, Catholic Nuns and Sisters in a Secular Age is based on a combination of 24 archival collections and 97 oral history interviews. According to Mangion she never intended to write a book on the post war era, but almost two decades of interaction with women religious while researching in numerous convent archives drew her to delve deeper into how women religious fit into the maelstrom of British post-war social change, and examine the continuum of change as women religious reexamined their purpose as prompted by the Second Vatican Council in the mid-1960s. Among its strengths, Catholic Nuns and Sisters in a Secular Age is a much-needed addition to the growing historiography of secularization. As Mangion notes in her conclusion, "The post-secular view of Catholic Nuns and Sisters in a Secular Age acknowledges secularization, but examines the influence of

ISSN 2560-8371

DOI: 10.24908/encounters.v21i0.14448

(C) Encounters in Theory and History of Education | 276 
religious and social change in the destructuring and restructuring of Catholic female religious life."

\section{Conversation}

Heidi MacDonald: After years of archival research on the $19^{\text {th }}$ century, you depended primarily on almost 100 oral interviews for this book. Are you a permanent convert to oral history, or will you joyfully return to the dust of the archives?

Dr Carmen M. Mangion: Catholic Nuns and Sisters in a Secular Age utilized both archival sources and oral histories in part because I love the dust of the archives.

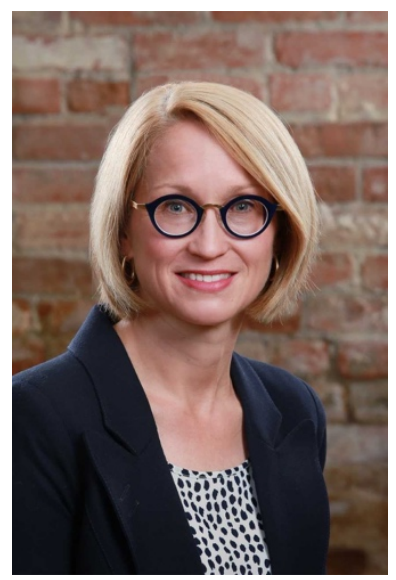

Heidi MacDonald

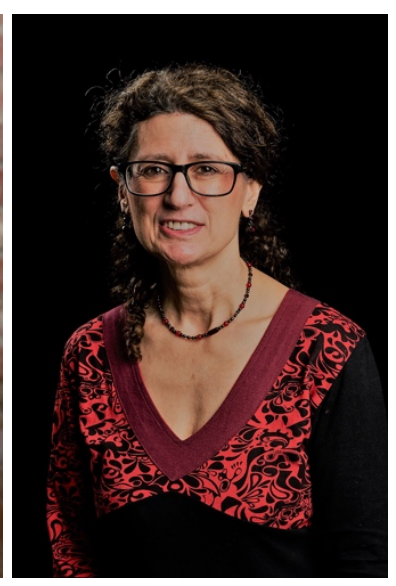

Dr Carmen M. Mangion

The archival sources, in the main, told more of an administrative story. The documents that I examined were part of the corporate history of a community. I wanted to understand more about the experience of living through such turbulent changes. The oral testimony allowed me to get closer to that lived experience of what was for many a very complex, exhilarating and discomfiting time. And the remembered experience of these times really varied from sister to nun. I used a life history approach which gave me a more holistic understanding of each woman's life - and honestly, I enjoyed the listening to each and every story.

I hope to always use archives! And even hope to go back to the nineteenth century but the next book will prob be on first half of the twentieth century so back to the archives!

HM: What are the biggest myths your book dispels (a) for the average nonCatholic, and (b) for the average religious scholar?

CMM: (a) I think the general public identifies 'the nun' by using a variety of tropes fed by media and films. Either nuns are very pious and holy; or nuns are activists like the 'nuns on the bus'; or they are cruel and heartless nuns who run Magdalen institutions. The women I met were quite ordinary women who felt called to live a religious life. And though they entered what seemed to be very enclosed communities, these communities were not hermetically sealed the world. The book charts these social changes within religious life but maps it on to the changes that are also happening in wider society particularly those associated with the 1960 s. So, I have chapters that address the difficult movement towards participatory democracy, experimental 
approaches to community living that alter the formality of religious life to make it more relational; to the change in ministries. Even enclosed nuns, like the Poor Clares (on the cover of the book), in trying to encourage vocations, open up to the world and accept the offer from journalist Alan Whicker, to become the subject of a popular British television programme 'Whicker's World where the camera and the crews and Whicker enter the monastery, and the monastery enters British living rooms. (This was like a 1970 s version of a reality tv programme!)

(b) I think academic scholars and Catholics think that the Second Vatican Council was a time of great change - and so it was to a point. But the changes in religious life did not begin with the Council. There was so much happening with regards to changes in religious life in the 1940s and 1950s. I write about the discourse of the 'modern girl' who was entering religious life in the 1940s and 1950s - she was seen as idealistic and questioning and novitiate training needed to be modified. Many (not all) women religious were given more opportunities for education - they were sent to teacher training colleges and universities. This initial push for modernization comes from the Holy See because they are so concerned about what they were seeing in many European countries, including Britain, was that young women weren't entering religious life. Sisters were an important labour force for the Catholic Church, managing schools, hospitals and welfare institutions so this was potentially a difficult situation for the Church.

Many convents were changing even before the Second Vatican Council. A lot of those women who were educated in the 1940s and 1950s were now in leadership positions in the 1960s. I think they would have been more open to the social changes so there would have been I think some changes.

I'm not sure the change in governance would have happened so quickly. The Holy See insisted on these 'aggiornamento chapters' which were held in 1968/9. And I wonder if changes in ministries would have occurred as they did. That said, even with the Vatican Council and liberation theology, decisions to change ministries, particularly to leave schools, were slow to happen in many convents in Britain.

\section{HM: How much does your book intersect with the history of education in Britain?}

CMM: Many of these sisters were members of teaching congregations that were responsible for Catholic education. Though I don't focus as much on what happens in the classroom or pedagogy, it is important to understand that as educators, teaching sisters were becoming more university-trained and were becoming free to join and become involved in professional organizations.

In the chapter on changing ministries, I outline the real contested nature of the moving away from the traditional ministries. This was especially difficult for teaching congregations, and I highlight some sisters' voices with regards to these real difficulties. The reality was, as I point out, not only that sisters wanted to explore more 
social justice oriented ministries, but also that numbers were declining and communities were aging, and sisters would no longer staff schools as they had.

I also discuss briefly how Catholic schooling is influenced by ideas of social justice and liberation theology and how ideas of social justice entered the classroom. I touch upon this briefly, but surely this could be the subject of future MA and PhD dissertations!

\section{HM: Having spent so much time interviewing nuns and sisters in the last few years, do you have any predictions on their future?}

CMM: All I know is that there has been several times in the two millennium history of religious life where there were many who thought the end of religious life was around the corner. The large numbers of women that entered communities in the nineteenth century were unparalleled in the history of religious life and met social needs for education, social welfare and health care that are now met (in many nations) by the State.

Of course, many, many congregations and communities are diminishing and will 'come to conclusion'. However, the media does seem to be inordinately focused on the Global North and religious life in some places in the Global South is still attractive to women. Approximately 60 per cent of 1.2 billion Catholics live outside of North America and Europe, and the biggest recent growth in Catholic congregations is in Africa where religious life is vibrant relative to religious life in North America and Europe.

Sociologists talk about paradigm changes and maybe that's where we are now.

\section{Note}

1. Carmen M. Magnion, Catholic Nuns and Sisters in a Secular Age: Britain, 1945-90 (Manchester University Press, 2020), 344 pages, paperback, ISBN: 978-1-5261-56068, £25. https://manchesteruniversitypress.co.uk/9781526156068/ 